\title{
Expression of cationic amino acid transporters, carcass traits, and performance of growing pigs fed low-protein amino acid-supplemented versus high protein diets
}

\author{
A. Morales ${ }^{1}$, F. Grageola ${ }^{1}$, H. García ${ }^{1}$, A. Araiza ${ }^{1}$, R.T. Zijlstra ${ }^{2}$ and \\ M. Cervantes ${ }^{1}$ \\ ${ }^{1}$ Instituto de Ciencias Agrícolas, Universidad Autónoma de Baja California, \\ Mexicali, México \\ ${ }^{2}$ Department of Agricultural, Food and Nutritional Science, \\ University of Alberta, Edmonton, Alberta, Canada \\ Corresponding author: M. Cervantes \\ E-mail: miguel_cervantes@uabc.edu.mx
}

Genet. Mol. Res. 12 (4): 4712-4722 (2013)

Received October 29, 2012

Accepted August 15, 2013

Published October 18, 2013

DOI http://dx.doi.org/10.4238/2013.October.18.9

\begin{abstract}
Free amino acids (AA) appear to be absorbed faster than protein-bound AA (PB-AA). We conducted an experiment to assess the effect of feeding pigs with a partially free (F-AA) or totally PB-AA diet on expression of selected genes and performance of pigs. The expression of cationic AA transporters $\mathrm{b}^{0,+}$ and CAT-1 in intestinal mucosa, liver, and longissimus (LM) and semitendinosus (SM) muscles, as well as that of myosin in LM and SM, was analyzed. Twelve pigs (31.7 \pm 2.7 $\mathrm{kg}$ ) were used. The F-AA diet was based on wheat, supplemented with $0.59 \%$ L-Lys, $0.33 \%$ L-Thr, and $0.10 \%$ DL-Met. The PB-AA diet was formulated with wheat-soybean meal. Average daily feed intake was $1.53 \mathrm{~kg}$ per pig. The expression of $\mathrm{b}^{0,+}$ and CAT- 1 was analyzed in jejunal and ileal mucosa, liver, LM, and SM; myosin expression was also analyzed in both muscles. Pigs fed the PB-AA diet tended to have
\end{abstract}


higher weight gain and feed efficiency $(\mathrm{P}<0.10)$, and had thinner back fat $(\mathrm{P}=0.02)$. The expression of $\mathrm{b}^{0,+}$ was higher $(\mathrm{P}<0.01)$ in jejunum but lower $(\mathrm{P}<0.01)$ in the liver of pigs fed the F-AA diet; CAT-1 tended to be lower in liver but higher in LM of PB-AA pigs. Myosin expression was not affected. Intestinal AA absorption was faster in pigs fed the F-AA diet, but AA uptake by the liver seemed to be faster in pigs fed the PB-AA. Performance and expression of AA transporters and myosin suggest that the dietary content of free or protein-bound AA does not affect their availability for protein synthesis in pigs.

Key words: Pigs; Free amino acids; Protein-bound; Gene expression; Performance

\section{INTRODUCTION}

The reduction in the dietary crude protein content $(\mathrm{CP})$, coupled with the supplementation of crystalline AA, is used to improve the AA profile and to reduce $\mathrm{N}$ excretion in pigs. However, the performance response of pigs fed low-protein, free AA supplemented diets (F-AA) has not been consistent. Some reports show that a reduction of four or less CP percentage units in corn-soybean meal (SBM) diets does not affect the performance and carcass characteristics of finishing pigs (Tuitoek et al., 1997; Knowles et al., 1998; Le Bellego et al., 2002). Moreover, Barrera et al. (2004) showed that free Lys and Thr could replace SBM completely in wheat diets for growing pigs without affecting their performance. However, other reports show a decreased performance and thicker back fat when $\mathrm{CP}$ was reduced by four or more percentage units in cornor sorghum-SBM diets (e.g., Brudevold and Southern, 1994; Tuitoek et al., 1997; Yue and Qiao, 2008). Several factors are believed to be responsible for the lower performance, including differences in the energy system (ME vs NE) used for diet formulation (Noblet et al., 1994), energy content (Kerr et al., 2003), AA profile (Brodevuld and Southern, 1994), absorption and protein accretion rate (Tuitoek et al., 1997), but controversy still remains. However, to our knowledge, no one has analyzed factors such as the abundance of AA transporters that affect the absorption and availability of AA in pigs fed (F-AA), as compared to those fed only protein-bound AA (PB-AA).

Lys is the first limiting AA in most cereal-SBM diets for pigs (NRC, 1998), but Arg and Leu are supplied in excess. Both Arg and Lys are absorbed by the enterocyte, at high affinity, by the Na-independent transporters $\mathrm{b}^{0,+}$ (Majumder et al., 2009) and CAT-1 (Hatzoglou et al., 2004). The $\mathrm{b}^{0,+}$ system is the most important transporter for cationic AA expressed in epithelial cells, whereas CAT-1 is expressed in non-epithelial cells (Palacin et al., 2001). The $\mathrm{b}^{0,+}$ system exchanges Leu for Lys (Torras-Llort et al., 2001), indicating that the intestinal absorption of Lys is coupled with the efflux of Leu. A recent report shows that the dietary content of Leu and Lys affects the absorption of Lys (García-Villalobos et al., 2012). F-AA diets not only contain lower Arg and Leu levels but also a high percentage of free Lys, from $44 \%$ (Kerr et al., 2003) to $70 \%$ (Barrera et al., 2004) of total Lys. Since protein-bound AA need to be released by pancreatic and intestinal enzymes prior to their absorption, free AA may be absorbed faster and their availability for protein synthesis could be higher (Rerat et al., 1992). Hatzoglou et al. (2004) found that the expression of cationic AA transporters in vitro was regulated by the content of cationic AA. Assuming that the expression of AA transporters fully represents their 
activity (Dave et al., 2004; Hatzoglou et al., 2004), it is speculated that the concentration of free AA in intestinal contents and in the extracellular fluid of liver and muscle, affects the expression of AA transporters, thereby the absorption and availability of AA in pigs.

A diet formulated with wheat as the sole major ingredient is highly deficient in Lys, Thr, and Met for growing pigs, but these AA are currently available in free form at competitive prices and can be added to the diet without affecting the dietary levels of the other AA. Excesses of other AA are eliminated in the F-AA diet although Ile, Leu and Val become marginal; these AA are not presently available as feed-grade in Mexico. Moreover, a wheat-based, F-AA diet contains around two-thirds free and one-third protein-bound Lys. The objective of this study was to evaluate the effect of a F-AA diet (supplemented with free Lys, Thr and Met, and no excess AA) or a PB-AA diet (some excess AA), on the expression of genes coding for $\mathrm{b}^{0,+}$ and CAT-1 in jejunum, ileum, liver, and longissimus (LM) and semitendinosus (SM) muscles, as well as for myosin in the LM and SM. The relationships of these variables with growth performance and carcass characteristics were also analyzed.

\section{MATERIAL AND METHODS}

\section{Animals and housing}

The care of the pigs used in the study was in accordance with the guidelines established in the Official Mexican Regulations on Animal Care (NOM-062-Z00-1999, 2001). Twelve crossbred (Landrace x Hampshire x Duroc) pigs (31.7 $\pm 2.7 \mathrm{~kg}$ initial body weight) were distributed into two groups on the basis of initial weight, sex, and litter. There were 6 replicates ( 3 barrows and 3 gilts) per treatment. Pigs were individually housed in raised floor metabolism pens $(1.2 \mathrm{~m}$ wide, $1.2 \mathrm{~m}$ long and $1.0 \mathrm{~m}$ high) equipped with a stainless-steel self-feeder, a nipple water drinker, and iron mesh floor in a temperature-controlled room $\left(22^{\circ}\right.$ $24^{\circ} \mathrm{C}$ ). Feed intake was restricted and adjusted every week to $1.3,1.45$ and $1.85 \mathrm{~kg} / \mathrm{day}$ for weeks 1,2 and 3, respectively (average $1.53 \mathrm{~kg} /$ day). Feed was provided twice a day, at 0700 and $1700 \mathrm{~h}$. All pigs were trained to consume the same amount of feed within $30 \mathrm{~min}$ or less and had unlimited access to water. Pigs were weighed at the start and end of the 23-day study to calculate the average daily weight gain (ADG) and the weight gain:feed intake ratio (GF). The average body of the pigs at the end was $47.2 \pm 0.88 \mathrm{~kg}$.

\section{Diets}

The pigs were fed a F-AA or PB-AA diet (Table 1). The F-AA diet was formulated with wheat as the sole major ingredient (most common ingredient used under practical conditions in northern Mexico), with added 0.59\% L-Lys, 0.33\% L-Thr, and 0.10\% DL-Met. This diet met the SID requirement of Lys, Thr and Met for growing pigs (NRC, 1998). The PB-AA diet was formulated with wheat and SBM to contain $0.83 \%$ SID Lys, but supplied excesses of the other essential AA. The F-AA diet contained $62 \%$ total Lys in free form and $38 \%$ as protein-bound; in contrast, the PB-AA diet contained only protein-bound Lys. Both diets met or exceeded the NRC (1998) requirements of vitamins and minerals, and contained 13.8 MJ $\mathrm{ME} / \mathrm{kg}$ feed. Diets were analyzed (Table 2$)$ for CP (method 984.13; AOAC, 2006) and AA (method 982.30; AOAC, 2006). 
Table 1. Formulation of the low protein-amino acid (AA) supplemented and high protein diets (as-fed basis).

\begin{tabular}{lcc}
\hline Ingredient (\%) & & Diets \\
\cline { 2 - 3 } & Low protein + AA & High protein \\
\hline Wheat & 96.52 & 75.20 \\
Soybean meal $(48 \% \mathrm{CP})$ & & 21.30 \\
L-Lysine $\mathrm{HCl}(78.5 \%)$ & 0.75 & \\
L-Threonine & 0.33 & 0.50 \\
DL-Methionine & 0.10 & 1.35 \\
Soybean oil & 1.35 & 0.40 \\
Calcium carbonate & 0.40 & 0.35 \\
Orthophosphate & 0.35 & 0.20 \\
Iodized salt & 0.20 & \\
Vitamin Mineral Premix & & \\
\hline CP & &
\end{tabular}

$\mathrm{CP}=$ protein content ${ }^{\text {aS }}$ upplied per kilogram of diet: vitamin A, $4800 \mathrm{IU}$; vitamin $\mathrm{D}^{3}, 800 \mathrm{IU}$; vitamin $\mathrm{E}$, $4.8 \mathrm{IU}$; vitamin K3, $1.6 \mathrm{mg}$; riboflavin, $4 \mathrm{mg}$; D-pantothenic acid, $7.2 \mathrm{mg}$; niacin, $16 \mathrm{mg}$; vitamin $\mathrm{B}^{12}, 12.8 \mu \mathrm{g}$; $\mathrm{Zn}, 64 \mathrm{mg}$; Fe, $64 \mathrm{mg}$; Cu, $4 \mathrm{mg}$; Mn, $4 \mathrm{mg}$; I, $0.36 \mathrm{mg}$, and Se, $0.13 \mathrm{mg}$.

Table 2. Content of crude protein and amino acid (AA) analyzed, and ME content calculated in the low proteinAA supplemented and high protein diets (as-fed basis).

\begin{tabular}{lcc}
\hline Item, \% & & Diets \\
\cline { 2 - 3 } & Low protein + AA & High protein \\
\hline Crude protein & 11.10 & 20.30 \\
Arginine & 0.58 & 1.27 \\
Histidine & 0.30 & 0.44 \\
Isoleucine & 0.45 & 0.85 \\
Leucine & 0.87 & 1.45 \\
Lysine & 0.95 & 0.96 \\
Methionine & 0.31 & 0.51 \\
Phenylalanine & 0.60 & 1.46 \\
Threonine & 0.64 & 0.75 \\
Valine & 0.54 & 1.02 \\
Calculated ME content $(\mathrm{MJ} / \mathrm{kg})$ & 13.79 & 13.76 \\
\hline
\end{tabular}

\section{Tissue collection and carcass evaluation}

At the end of the experiment, all pigs were euthanized by electrical stunning and exsanguination for evaluation of carcass characteristics and for tissue collection, three hours after their last feeding at $0700 \mathrm{~h}$. The corpses were immediately eviscerated, and mucosal samples scratched from middle jejunum and terminal ileum (approximately $0.5 \mathrm{~g}$ ) were collected into 2-mL Eppendorf microtubes. Samples from liver, LM and SM (approximately 0.5 to 1.0 g) were also collected. All samples were immediately frozen in liquid nitrogen, and stored at $-82^{\circ} \mathrm{C}$ until analysis. The total collection process took no longer than 8 min to maximize the quality of the extracted RNA. Carcass characteristics were evaluated, and carcass protein content $(\mathrm{kg})$ was estimated according to Whittemore et al. (2003).

\section{Total RNA extraction and purification}

Samples of intestinal (jejunum and ileum) mucosa, liver, LM and SM were treated to extract total RNA by pulverization in liquid nitrogen (Méndez et al., 2011) following the instructions for the Trizol reagent (Invitrogen Corp., Carlsbad, CA, USA). Purified RNA was 
eluted with $30 \mu \mathrm{L}$ of RNase-free distilled water and stored at $-82^{\circ} \mathrm{C}$. The concentration of total RNA was determined spectrophotometrically (Helios $\beta$, Thermo Electron Co., Rochester, NY, USA) at $260 \mathrm{~nm}$, and purity of RNA was assessed by the A260/A280 ratio, which ranged from 1.8 to 2.0 (Sambrook and Russell, 2001). The integrity of total RNA was evaluated by gel electrophoresis on $1 \%$ agarose gels. All RNA samples showed good quality with a $28 \mathrm{~S}: 18 \mathrm{~S}$ rRNA ratio around 2.0:1 (Sambrook and Russell, 2001).

\section{Reverse transcription}

Approximately $2 \mu \mathrm{g}$ total RNA were treated with $1 \mathrm{U}$ DNase I $(1 \mathrm{U} / \mu \mathrm{L}$; Invitrogen Corp.) and $6 \mu \mathrm{L} 5 \mathrm{X}$ reverse transcription buffer in a $30-\mu \mathrm{L}$ reaction mixture completed with DEPC treated water; the reaction was carried out for $15 \mathrm{~min}$ at room temperature and another 15 min at $70^{\circ} \mathrm{C}$ to stop the reaction. Reverse transcription was initiated with DNase-treated RNA samples, adding $1 \mu \mathrm{L}$ random primers $(150 \mathrm{ng} / \mu \mathrm{L}$, Invitrogen) and $1 \mu \mathrm{L}$ dNTPs solution (10 $\mu \mathrm{M}$ each), and the tubes were incubated at room temperature and then chilled on ice for $1 \mathrm{~min}$. Next, $3 \mu \mathrm{L}$ DTT $(0.1 \mathrm{M}), 1 \mu \mathrm{L}$ ribonuclease inhibitor ( $40 \mathrm{U} / \mu \mathrm{L}$; RNase OUT, Invitrogen) and 2 $\mu \mathrm{L} 5 \mathrm{X}$ reverse transcription buffer were added, and the reaction mixture incubated at $42^{\circ} \mathrm{C}$ for 2 min to stabilize the reaction before adding $1 \mu \mathrm{L}$ reverse transcriptase enzyme $(200 \mathrm{U} / \mu \mathrm{L}$; RTSuperscript III, Invitrogen). The reaction mixture was then incubated at $42^{\circ} \mathrm{C}$ for $50 \mathrm{~min}$. The mixture was next incubated at $70^{\circ} \mathrm{C}$ for $15 \mathrm{~min}$ and then chilled on ice to stop the reaction. cDNA samples were quantified spectrophotometrically and diluted to a final concentration of $50 \mathrm{ng} / \mu \mathrm{L}$.

Specific primers for the amino acid transporters $\mathrm{b}^{0,+}$ and CAT-1, and myosin (heavy chain of isoform IIB) mRNA and 18S rRNA were designed according to their published sequences in GenBank (Table 3). Type IIB fibers account for about $80 \%$ of the total fibers in some pig muscles (Czerwinski and Martin, 1994) and are extensively expressed in LM and SM of pigs (Lefaucheur et al., 2002). Also, a housekeeping 18S rRNA (GenBank AY265350) was used as an endogenous control to normalize variations in mRNA. Before starting, end point PCR was carried out to standardize the amplification conditions for each pair of primers, and to confirm the specificity of the PCR products related to their mRNA, a sample of every PCR product was cloned into a TOPO vector 4.0 (Invitrogen) and sequenced at the Davis Sequencing Facility (Davis, CA, USA).

\begin{tabular}{|c|c|c|c|c|}
\hline mRNA & Primer & Location (bp) on the template & Sequence & Amplicon size (bp) \\
\hline \multicolumn{5}{|c|}{$\mathrm{b}^{0,+}$ AT (SLC7A9) (GenBank accession No. EF127857) } \\
\hline & Forward & $1-19$ & 5'-CGGAGAGAGGATGAGAAGT-3' & \multirow[t]{2}{*}{562} \\
\hline & Reverse & $545-562$ & 5'GCCCGCTGATGATGATGATGA-3' & \\
\hline \multicolumn{5}{|c|}{ Cationic amino acid transporter-1, CAT-1 (GenBank accession No. AY371320) } \\
\hline & Forward & $4239-4258$ & 5'-GTCGGTTGCAAAGACCATTT-3' & 329 \\
\hline & Reverse & $4548-4567$ & 5'-GAGCGGTGCTGACAACAGTA-3' & \\
\hline \multicolumn{5}{|c|}{ Myosin, heavy chain 4 (GenBank accession No. NM_001123141) } \\
\hline & Forward & $4582-4599$ & 5'-AGATTTCTGACCTGACTG-3' & 340 \\
\hline & Reverse & $4904-4921$ & 5'-TCTCCCTCCATCTTCTTC-3' & \\
\hline \multicolumn{5}{|c|}{ 18S rRNA (GenBank accession No. AY265350) } \\
\hline & Forward & $236-255$ & 5'-GGCCTCACTAAACCATCCAA-3' & 295 \\
\hline & Reverse & $511-530$ & 5'-TAGAGGGACAAGTGGCGTTC-3' & \\
\hline
\end{tabular}


Expressions of $\mathrm{b}^{0,+}, \mathrm{CAT}-1$, and myosin were estimated by quantitative PCR (qPCR) assays, using the Maxima SYBR Green/ROX qPCR Master Mix (Fermentas Corp., Glen Burnie, MD, USA) in a Chromo 4-DNA Engine with the MJ Opticon Monitor 3.1 software (Bio-Rad, Herefordshire, England). The equipment was calibrated with a standard curve using the $18 \mathrm{~S}$ rRNA cloned into a TOPO vector 4.0, from which a calibrator cDNA was produced. The standard curve was obtained using known concentrations of 100-fold serial dilutions of the cDNA. Reactions for qPCR contained $50 \mathrm{ng}$ cDNA, $0.5 \mu \mathrm{M}$ each specific primer, $12.5 \mu \mathrm{L} 2 \mathrm{X}$ SYBR (green/ROX qPCR Master Mix), and DNase-/RNase-free water to complete a final volume of $25 \mu \mathrm{L}$. The PCR conditions used for the amplification and quantification were an initial denaturation $\left(95^{\circ} \mathrm{C}\right.$ for 1 min), followed by 45 cycles of amplification (denaturation at $95^{\circ} \mathrm{C}$ for $30 \mathrm{~s}$, annealing at $56^{\circ} \mathrm{C}$ for $15 \mathrm{~s}$, and extension at $72^{\circ} \mathrm{C}$ for $\left.30 \mathrm{~s}\right)$ and a melting curve program $\left(60^{\circ} \mathrm{C}\right.$ to $\left.90^{\circ} \mathrm{C}\right)$. Fluorescence was measured at the end of every cycle and every $0.2^{\circ} \mathrm{C}$ during the melting program.

\section{Statistical analysis}

Analyses of variance were performed using the GLM of SAS (Statistical Analysis System 9.1, SAS Institute, Cary, NC, USA). Mean comparisons were performed using the Student $t$-test. Probability levels of $\mathrm{P} \leq 0.05$, and $0.05<\mathrm{P} \leq 0.10$ were defined as significant differences and tendencies, respectively.

\section{RESULTS}

All pigs remained healthy during the whole experiment. Previous studies have revealed that $18 \mathrm{~S}$ rRNA expression is very stable and its level can be used as an endogenous control to normalize the expression of other genes in response to various stimuli (Liao et al., 2009). In this study, we also chose to normalize the relative expression of $\mathrm{b}^{0,+}$, CAT-1, and myosin mRNA to $18 \mathrm{~S}$ rRNA expression by small intestinal epithelia and muscles. The realtime qPCR assays conducted in this study were validated by sequencing their final products at the Davis Sequencing Facility. Sequencing results revealed that the products for $b^{0,+}$, CAT-1, myosin, and $18 \mathrm{~S}$ rRNA showed $100 \%$ homology with their corresponding expected sequences acquired from the virtual template sequences reported in GenBank.

The performance results are presented in Table 4. Feed intake was restricted to 1.53 $\mathrm{kg} /$ day for all pigs. ADG $(\mathrm{P}=0.052)$ and $\mathrm{GF}(\mathrm{P}=0.053)$ tended to be higher, and weight gain:Lys intake was higher $(\mathrm{P}=0.025)$ in pigs fed the PB-AA diet. The results of the carcass characteristics are shown in Table 5. The back fat depth was smaller $(\mathrm{P}=0.018)$ in pigs fed the PB-AA diet, but there was no effect on loin eye area $(\mathrm{P}=0.722)$, weight of hot carcass $(\mathrm{P}=$ $0.814)$, and content $(\mathrm{kg})$ of fat-free lean $(\mathrm{P}=0.107)$ and protein $(\mathrm{P}=0.085)$ in carcass.

The mRNA expression results are shown in Table 6. The transporter $\mathrm{b}^{0,+}$ was more expressed in jejunum but less expressed in liver of pigs fed the F-AA diet $(\mathrm{P}<0.001)$ as compared to pigs fed the PB-AA diet; there was a negative correlation in the expression of $\mathrm{b}^{0,+}$ between jejunum and liver $(\mathrm{r}=-0.83 ; \mathrm{P}<0.001)$. There were no differences between treatments in the expression of $\mathrm{b}^{0,+}$ in ileum $(\mathrm{P}=0.473), \mathrm{LM}(\mathrm{P}=0.393)$, and SM $(\mathrm{P}=0.613)$. The expression of $\mathrm{b}^{0,+}$, regardless the dietary treatment, was higher in ileum than in jejunum $(\mathrm{P}=0.015)$.

The expression of CAT- 1 tended to be higher in liver $(\mathrm{P}=0.057)$ but lower in LM $(\mathrm{P}=$ 0.056) of pigs fed the F-AA diet as compared to those fed the PB-AA diet; no differences were 
observed in jejunum, ileum or SM. There was no treatment effect on myosin expression in either LM $(\mathrm{P}=0.433)$ or SM $(\mathrm{P}=0.999)$. The expression of CAT-1 was lower $(\mathrm{P}=0.014)$ in ileum as compared to jejunum.

Table 4. Performance of average daily weight gain and weight gain: feed intake ratio, of pigs fed wheat-based, low-protein amino acid supplemented (LP-AA) or high protein (HP) diets.

\begin{tabular}{lcccc}
\hline Item & \multicolumn{2}{c}{ Dietary treatment } & & SE \\
\cline { 2 - 4 } & LP-AA & HP & 709 & 0.022 \\
Average daily weight gain (g/day) & 642 & 1.53 & - & 0.052 \\
Feed intake (kg/day) & 1.53 & 14.6 & - & - \\
Lys intake (g/day) & 14.6 & 0.460 & 0.014 & 0.053 \\
Weight gain:feed intake ratio & 0.420 & 48.7 & 1.48 & 0.025 \\
Weight gain:Lys intake ratio & 44.1 & &
\end{tabular}

$* \mathrm{~N}=6$.

Table 5. Carcass characteristics of pigs fed wheat-based, low-protein amino acid supplemented (LP-AA), or high protein (HP) diets.

\begin{tabular}{lcccc}
\hline & \multicolumn{2}{c}{ Dietary treatment } & & SE \\
\cline { 2 - 3 } Item & LP-AA & HP & 0.782 & P value \\
\hline Hot carcass weight $(\mathrm{kg})$ & 25.8 & 26.1 & 0.966 & 0.814 \\
Loin eye area $\left(\mathrm{cm}^{2}\right)$ & 25.0 & 24.5 & 0.058 & 0.722 \\
Back fat (cm) & 1.08 & 0.85 & 0.014 & 0.018 \\
Protein content $\left(\mathrm{kg}^{\mathrm{a}}\right)$ & 6.57 & 6.61 & 0.373 & 0.085 \\
Fat-free lean weight $(\mathrm{kg})$ & 19.3 & 20.2 & 1.539 & 0.107 \\
Fat-free lean weight $(\%)$ & 89.0 & 91.0 & 0.391 \\
\hline
\end{tabular}

${ }^{a}$ Calculated with the equation of Kloareg et al. (2006).

Table 6. Expression of $\mathrm{b}^{0,+}$ and CAT-1 in two small intestine segments (jejunum and ileum), liver, longissimus dorsi and semitendinosus muscles, and myosin in these muscles of pigs fed either a low-CP diet supplemented with free Lys, Thr, and Met or a high protein diet (arbitrary units: ratio of mRNA:18S rRNA).

\begin{tabular}{|c|c|c|c|c|c|}
\hline \multirow[b]{2}{*}{ Transporter } & \multirow[b]{2}{*}{ Tissue } & \multicolumn{2}{|c|}{ Dietary treatment } & \multirow[b]{2}{*}{ SE } & \multirow[b]{2}{*}{ P value } \\
\hline & & LP-AA & HP & & \\
\hline \multirow[t]{5}{*}{ b0,+ } & Jejunum & 0.1037 & 0.0405 & 0.0069 & $<0.001$ \\
\hline & Ileum & 0.3482 & 0.5706 & 0.2110 & 0.473 \\
\hline & Liver & 0.0029 & 0.0134 & 0.0013 & $<0.001$ \\
\hline & Longissimus & 0.0059 & 0.0049 & 0.0008 & 0.393 \\
\hline & Semitendinosus & 0.0018 & 0.0011 & 0.0089 & 0.613 \\
\hline \multirow[t]{5}{*}{ CAT-1 } & Jejunum & 0.0093 & 0.0247 & 0.0070 & 0.170 \\
\hline & Ileum & 0.0023 & 0.0024 & 0.0006 & 0.976 \\
\hline & Liver & 0.0052 & 0.0008 & 0.0015 & 0.057 \\
\hline & Longissimus & 0.0033 & 0.0087 & 0.0018 & 0.056 \\
\hline & Semitendinosus & 0.0033 & 0.0217 & 0.0106 & 0.246 \\
\hline \multirow[t]{2}{*}{ Myosin } & Longissimus & 0.0047 & 0.0060 & 0.0011 & 0.433 \\
\hline & Semitendinosus & 0.0045 & 0.0045 & 0.0009 & 0.999 \\
\hline
\end{tabular}

$* \mathrm{~N}=6$.

\section{DISCUSSION}

The pigs used in this study were pair-fed to eliminate any potential effect that differences in daily feed intake (ADFI) would have on the variables evaluated here. The ADFI of these pigs was lower than the estimated value of NRC $(1998 ; 12 \%)$, or the value observed by Tuitoek et al. (1997; 
around 26\%) and by Kerr et al. (2003; around 16\%) in growing pigs. However, ADG of pigs in this study was approximately $18 \%$ lower than that reported by Tuitoek et al. (1997), and similar to that published by Kerr et al. (2003). These results show an acceptable performance even though ADFI was restricted and Ile, Leu and Val were marginal in the F-AA diet; this diet was slightly deficient in Ile, Leu and Val, but it had an AA profile closer to the ideal protein as compared to the PB-AA diet.

In the current study, ADG of live weight tended to be higher in pigs fed the PB-AA diet. However, when comparing the carcass traits of pigs fed either the F-AA or PB-AA diet, there were no differences in carcass protein and fat-free lean weight and loin eye area. Nieto et al. (2003) found a $7.7 \%$ increase in the weight of the gastrointestinal tract of $15-$ to $50-\mathrm{kg}$ pigs when the dietary protein content was raised from 10.1 to $22.3 \%$; the weight range of pigs in our study (32 to $47 \mathrm{~kg}$ ) and the dietary protein contents (11.0 and 20.3\%) were comparable to those reported by Nieto et al. (2003). These results suggest that the tendency for a higher live weight gain observed in pigs fed the PB-AA diet could be due to a heavier gastrointestinal tract and its contents.

A reduction in body protein accretion rate is suggested as one potential cause for the reduced performance of finishing pigs fed F-AA, corn- (Hansen et al., 1993; Tuitoek et al., 1997) or sorghum-based (Brudevold and Southern, 1994) diets. According to Czerwinski and Martin (1994), myosin is the most abundant protein in muscle cells, and the isoform IIB accounts for about $80 \%$ of the total fibers in some pig muscles; this isoform is extensively expressed in LM and SM (Lefaucheur et al., 2002). Furthermore, Brodsky et al. (2004) found that low intake of dietary protein reduced the synthesis of myosin in human, suggesting that myosin can be a good indicator of protein synthesis and accretion in pigs. In the current study, the expression of the IIB isoform of myosin mRNA in LM or SM was not different between pigs fed the F-AA and the PBAA diets, and was consistent with the lack of differences in loin eye area and protein weight in carcass. Since the protein synthesis process is regulated by the intracellular presence of available AA (Miyazaki and Esser, 2009), these results suggest that the availability of AA for muscle protein synthesis and accretion was not affected by the form (partially free or totally protein-bound) in which Lys, Thr, and Met were supplied. But, since both diets were AA unbalanced, it is not clear why back fat depth was larger in pigs fed the F-AA diet.

It is suggested that pigs fed low CP diets supplemented with crystalline AA have a lower performance because protein-bound AA in feed ingredients are digested and absorbed at a slower rate, as compared to free AA (Hansen et al., 1993). According to Rerat et al. (1992), free AA appear faster in portal blood than protein-bound AA, and could be oxidized before they are used for protein synthesis; this process requires that all AA are available within the cell in the right amount and at the same time (Kobayashi et al., 2003). Assuming the expression of cationic AA transporters represents their functional activity, the results of the current study agree with those published by Rerat et al. (1992) regarding AA absorption rate. But, concerning the AA oxidation rate, Nolles et al. (2009) found that, in the short term (5 days), free AA are oxidized faster than protein-bound, although this difference disappears after 20 days of adaptation. In our study, tissue samples were collected after more than 20 days of adaptation to the diets. According to those findings, no variation in oxidation rate between free and protein-bound AA would be expected at the end of our study.

The intestinal absorption and uptake of AA by liver and muscle cells involves the abundance, specificity, and activity of AA transporters (Broer, 2008) in particular tissues (Palacin et al., 2001; Torras-Llort et al., 2001), which in turn may be affected by the dietary concentration of each AA and the potential interactions between them (Kilberg et al., 2005). Lys and Arg are transported by the Na-independent systems $b^{0,+}$ and CAT-1 (Majumder et al., 2009); these are 
the major cationic AA transporters in mammals (Palacin et al., 2001; Broer, 2008). The transporter $b^{0,+}$ is mainly expressed in epithelial cells and functions as antiporter exchanging Leu for Lys; the absorption of Lys is coupled with the efflux of Leu. Thus, the abundance of $b^{0,+}$ is critical in pigs fed F-AA diets where Lys is mostly supplied in free form (62\%) and excess Leu is eliminated, but the PB-AA diet contained only protein-bound Lys and about $60 \%$ excess Leu. CAT-1 is mainly expressed in non-epithelial cells (Hatzoglou et al., 2004).

In this study, the expression of $\mathrm{b}^{0,+}$ in jejunum was 2.6 -fold higher in pigs fed the F-AA diet, which was expected because most Lys was readily available for absorption right after reaching the small intestine. Morales et al. (2012) also found a significant increase in the expression of $\mathrm{b}^{0,+}$ in jejunum of growing pigs fed low CP, as compared to PB-AA (11.0 vs 19.0\%) wheat-based diets. Yue and Qiao (2008) observed that reducing dietary CP concentration from 23.1 to $17.2 \%$ decreased the villous height in duodenum and jejunum; this suggests a decrease in the number of small intestine absorptive cells. Hence, this morphological change could also affect the villous capacity to produce AA transporters in the first two segments of the small intestine. However, the expression of $b^{0,+}$ in ileum in the current study was not affected by the form of dietary AA, and more importantly, it was 3.4 and 14.1 times higher than that observed in jejunum of pigs fed the F-AA and the PB-AA diet, respectively (Figure 1). These results may indicate that crystalline Lys in the F-AA diet was rapidly absorbed in jejunum whereas most of the Lys released from wheat and SBM proteins of the PB-AA diets was absorbed in ileum at a slow rate. In contrast, as shown in Figure 1, the expression of CAT-1 in ileum was 4.0 and 10.3 times lower than that in jejunum of pigs fed the F-AA and the PB-AA diet, respectively. Moreover, the expression of $\mathrm{b}^{0,+}$ in liver of pigs fed the PB-AA diet was 4.6-fold higher, but the expression of CAT-1 was 6.6-fold lower, as compared with those fed the F-AA diet. The expression of cationic AA transporters, as reported by several authors (e.g., Hatzoglou et al., 2004; Broer, 2008) represents their functional activity. Thus, the differences in expression of $\mathrm{b}^{0,+}$ and CAT-1 in jejunum, ileum, and liver appear to balance the differential absorption of cationic AA along the small intestine, and their uptake by liver. But, this assessment needs to be confirmed in further studies.

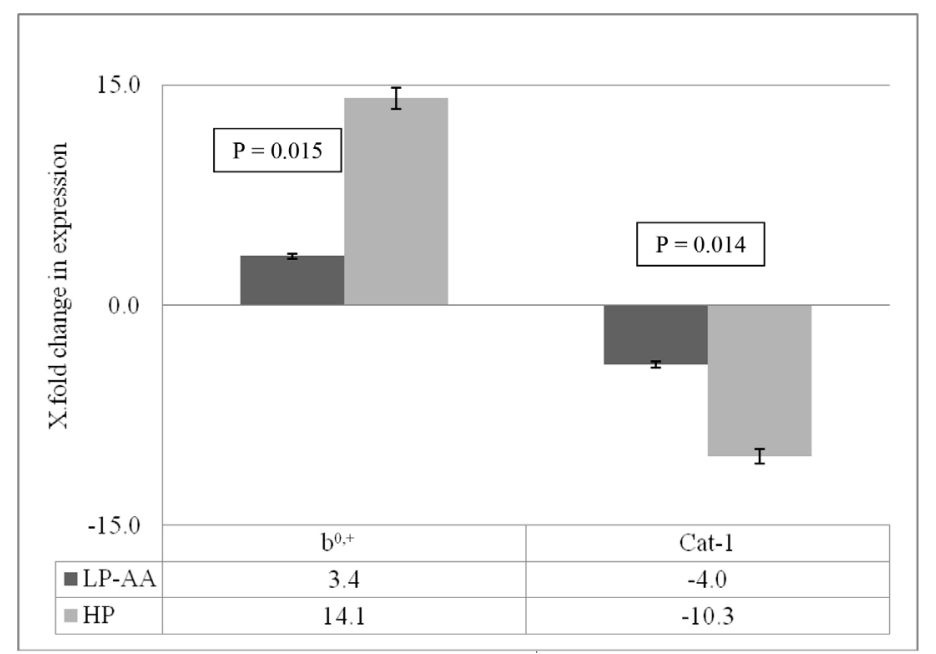

Figure 1. Change (x-fold) in the expression of $\mathrm{b}^{\mathrm{o},+}$ and CAT-1 in ileum, as compared to jejunum, in pigs fed the low protein diet supplemented with crystalline amino acids (LP-AA) or the high protein diet (HP). 
In conclusion, the expression of the cationic AA transporters $\mathrm{b}^{0,+}$ and CAT-1 in feedrestricted growing pigs appears to be differentially affected by the type (free or protein-bound) of dietary AA supplied, the tissue studied and the $\mathrm{CP}$ level. Free AA promotes a higher expression of $\mathrm{b}^{0,+}$ in jejunum but lower in liver, and regardless of the AA type, the expression of $\mathrm{b}^{0,+}$ is much higher in ileum as compared to jejunum. However, the differential effects of dietary free or PB-AA on the expression of these transporters appear to be balanced by the differential response of the two small intestine segments and liver. Pigs fed the PB-AA diet tended to have better performance but the loin eye area was not affected, and this response was associated with the lack of effect of the dietary CP level on the expression of myosin.

\section{ACKNOWLEDGMENTS}

Research supported by the National Science and Technology Council of México (CONACYT; scholarship to Fernando Grageola and Héctor García) and by the Universidad Autonoma de Baja California (Convocatoria Interna).

\section{REFERENCES}

AOAC (2006). Official Methods of Analysis. 18th ed. Assoc. Off. Anal. Chem, Arlington.

Barrera M, Cervantes M, Sauer WC, Araiza AB, et al. (2004). Ileal amino acid digestibility and performance of growing pigs fed wheat-based diets supplemented with xylanase. J. Anim. Sci. 82: 1997-2003.

Brodsky IG, Suzara D, Hornberger TA, Goldspink P, et al. (2004). Isoenergetic dietary protein restriction decreases myosin heavy chain IIx fraction and myosin heavy chain production in humans. J. Nutr. 134: 328-334.

Broer S (2008). Amino acid transport across mammalian intestinal and renal epithelia. Physiol. Rev. 88: 249-286.

Brudevold AB and Southern LL (1994). Low-protein, crystalline amino acid-supplemented, sorghum-soybean meal diets for the 10- to 20-kilogram pig. J. Anim. Sci. 72: 638-647.

Czerwinski SM and Martin JM (1994). Effect of somatotropin on myosin expression in pigs. J. Anim. Sci. 72: 1204-1208.

Dave MH, Schulz N, Zecevic M, Wagner CA, et al. (2004). Expression of heteromeric amino acid transporters along the murine intestine. J. Physiol. 558: 597-610.

García-Villalobos H, Morales-Trejo A, Araiza-Piña BA, Htoo JK, et al. (2012). Effects of dietary protein and amino acid levels on the expression of selected cationic amino acid transporters and serum amino acid concentration in growing pigs. Arch. Anim. Nutr. 66: 257-270.

Hansen JA, Knabe DA and Burgoon KG (1993). Amino acid supplementation of low-protein sorghum-soybean meal diets for 20- to 50-kilogram swine. J. Anim. Sci. 71: 442-451.

Hatzoglou M, Fernandez J, Yaman I and Closs E (2004). Regulation of cationic amino acid transport: the story of the CAT-1 transporter. Annu. Rev. Nutr. 24: 377-399.

Kerr BJ, Southern LL, Bidner TD, Friesen KG, et al. (2003). Influence of dietary protein level, amino acid supplementation, and dietary energy levels on growing-finishing pig performance and carcass composition. J. Anim. Sci. 81: 30753087.

Kilberg MS, Pan YX, Chen H and Leung-Pineda V (2005). Nutritional control of gene expression: how mammalian cells respond to amino acid limitation. Annu. Rev. Nutr. 25: 59-85.

Knowles TA, Southern LL, Bidner TD, Kerr BJ, et al. (1998). Effect of dietary fiber or fat in low-crude protein, crystalline amino acid-supplemented diets for finishing pigs. J. Anim. Sci. 76: 2818-2832.

Kobayashi H, Børsheim E, Anthony TG, Traber DL, et al. (2003). Reduced amino acid availability inhibits muscle protein synthesis and decreases activity of initiation factor eIF2B. Am. J. Physiol. Endocrinol. Metabol. 284: E488-E498.

Le Bellego L, van Milgen J and Noblet J (2002). Effect of high temperature and low-protein diets on the performance of growing-finishing pigs. J. Anim. Sci. 80: 691-701.

Lefaucheur L, Ecolan P, Plantard L and Gueguen N (2002). New insights into muscle fiber types in the pig. J. Histochem. Cytochem. 50: 719-730.

Liao SF, Vanzant ES, Harmon DL, McLeod KR, et al. (2009). Ruminal and abomasal starch hydrolysate infusions selectively decrease the expression of cationic amino acid transporter mRNA by small intestinal epithelia of foragefed beef steers. J. Dairy Sci. 92: 1124-1135. 
Majumder M, Yaman I, Gaccioli F, Zeenko VV, et al. (2009). The hnRNA-binding proteins hnRNP L and PTB are required for efficient translation of the Cat-1 arginine/lysine transporter mRNA during amino acid starvation. Mol. Cell Biol. 29: 2899-2912.

Méndez V, Avelar E, Morales A, Cervantes M, et al. (2011). A rapid protocol for purification of total RNA for tissues collected from pigs at a slaughterhouse. Genet. Mol. Res. 10: 3251-3255.

Miyazaki M and Esser KA (2009). Cellular mechanisms regulating protein synthesis and skeletal muscle hypertrophy in animals. J. Appl. Physiol. 106: 1367-1373.

Nieto N, Lara L, García MA, Vílchez MA, et al. (2003). Effects of dietary protein content and food intake on carcass characteristics and organ weights of growing Iberian pigs. Anim. Sci. 77: 47-56.

Noblet J, Fortune H, Shi XS and Dubois S (1994). Prediction of net energy value of feeds for growing pigs. J. Anim. Sci. 72: 344-354.

Nolles JA, Verreijen AM, Koopmanschap RE, Verstegen MW, et al. (2009). Postprandial oxidative losses of free and protein-bound amino acids in the diet: interactions and adaptation. J. Anim. Physiol. Anim. Nutr. 93: 431-438.

NOM-062-ZOO-1999 (2001). Especificaciones Técnicas para la Producción, Cuidado y Uso de los Animales de Laboratorio. Ochoa MLI. ed. Diario Oficial de la Federación, México, DF.

NRC (1998). Nutrient Requirements of Pigs, 10th Revised edn. National Academy Press, Washington, D.C.

Palacin M, Borsani G and Sebastio G (2001). The molecular bases of cystinuria and lysinuric protein intolerance. Curr. Opin. Genet. Dev. 11: 328-335.

Rerat A, Simoes-Nunes C, Mendy F, Vaissade P, et al. (1992). Splanchnic fluxes of amino acids after duodenal infusion of carbohydrate solutions containing free amino acids or oligopeptides in the non-anaesthetized pig. Br. J. Nutr. 68: 111-138.

Sambrook J and Russel DW (2001). Molecular Cloning: A Laboratory Manual. 3rd edn. Cold Spring Harbor Laboratory Press, New York.

Torras-Llort M, Torrents D, Soriano-García JF, Gelpí JL, et al. (2001). Sequential amino acid exchange across b0,+-like system in chicken brush border jejunum. J. Membr. Biol. 180: 213-220.

Tuitoek JK, Young LG, de Lange CFM and Kerr BJ (1997). The effect of reducing excess dietary amino acids on growingfinishing pig performance: an evaluation of the ideal protein concept. J. Anim. Sci. 75: 1575-1583.

Whittemore CT, Green D, Wood J and Fisher AV (2003). Physical and chemical composition of the carcass of three different types of pigs grown from 25 to $115 \mathrm{~kg}$ live weight. Anim. Sci. 77: 235245.

Yue LY and Qiao SY (2008). Effects of low-protein diets supplemented with crystalline amino acids on performance and intestinal development in piglets over the first 2 weeks after weaning. Livest. Sci. 115: 114-152. 